\title{
Primary head and neck cancers in North Eastern Nigeria
}

\author{
*E. C. Otoh ${ }^{1}$, N. W. Johnson ${ }^{2}$, I. S. Danfillo' ${ }^{1}$ O. A Adeleke ${ }^{1}$ and H. A. Olasojii ${ }^{3}$ \\ ${ }^{\prime}$ Regional Centre for Oral Health Research \& Training Initiatives, Jos, Nigeria \\ ${ }^{2}$ WHO Collaborating Centre for Oral Cancers \& Precancers, King's \\ College School of Medicine \& Dentistry, London, United Kingdom \\ ${ }^{3}$ Department of Oral \& Maxillofacial Surgery, University of Maiduguri Teaching Hospital \\ (UMTH), Maiduguri, Nigeria \\ E-mail.ccotoh@yahoo.co.uk
}

\begin{abstract}
Summary
Background:To document the pattern of primary head and neck cancers in North Eastern Nigeria.

Study DesignA record-based study of primary head and neck cancers histologically diagnosed at the University of Maiduguri Teaching Hospital (UMTH), Maiduguri, North Eastern Nigeria between 1987 and 2002.

Results: A total of 317 cases ( 20 cases per year) were diagnosed. The most common cancer sites were the oral cavity $(15.1 \%)$ and nasopharynx $(11.7 \%)$. Carcinomas $\mathbf{6 8 . 4 \% )}$ were the most common cancers reported, mostly affecting the oral cavity $(\mathbf{2 0 . 3 \%})$. Carcinomas were associated with farmers, kola nut chewers and tobacco users in this region, while kaposi sarcoma was the only cancer associated with HIV-positive patients. The overall mean duration of symptoms for cancers was $29.1 \pm$ 62.2 months. The mean duration for carcinomas was longer than for sarcomas $(p>0.05)$ and lymphomas $(p=$ $0.05) .81 \%$ of the staged cancers reported in the stage IV; while treated cancers required primary radiotherapy (51\%) or an adjuvant radical surgery and chemotherapy (9.4\%).

Conclusion: Intra-oral carcinomas were the most common histological types of cancers in the head and neck. The delay before and the cancer stage at presentation may be due to the lack of cancer management facilities and manpower in most of the hospitals in the region.
\end{abstract}

\section{Keywords: Head and Neck, Cancers, Nigerians}

\section{Résumé}

Les données de la gestion du cancer proviennent des dossiers médicaux et rapports pathologiques des 317 malades ( 20 cas par an) trouvés avec le cancer de la tête et du cou examiné par les Cliniques Universitaires de l'Université de Maiduguri, dans la région Nord Est du Nigeria entre 1987 et 2002. C'était des gens dont l'âge variait entre 40 et 60 ans (Rapport $\mathrm{H}-\mathrm{F}=1,8: 1$ ), avec $48,6 \%$ en dessous 40 ans. Les sites de cancer les plus fréquents étaient la cavité orale $(15,1 \%)$ et les pharynx nasaux $(11,7)$.

Les carcinomes $(68,4 \%)$ étaient les cas les plus communément rapportés. La plupart d'entre eux concernaient la cavité orale $(20.3 \%)$. Ils se rapportaient aux fermiers, aux consommateurs de la noix de kola et fumeurs de cigarettes dans cette région. Kaposi Sarcome était le seul type de cancer lié aux sero-positifs. La durée
}

moyenne des symptômes des cancers était de 2),1 $\pm 62,2$ mois. La durée moyenne des carcinomes était $\mathrm{p}$ us longue que celle du sarcasmes ( $p>0,05)$. Il y avait $81 \%$ c es cancers rapportés dans leur quatrième niveau ; $51 \%$ des cas traités exigeant la radiothérapie et $9,4 \%$ exigeant la rad iothérapie accompagnée d' une sérieuse opération chirurg cale et de la chemotherapie.

Les carcinomes intra-oraux étaient les plus fréqu ents types histologiques de cancer de la tête et du cou. Le délai et le retard dans la présentation et la prédiction inac équate de ces cas pourrait entre dues au manque de pe sonnel et d'équipement approprié à la gestion de cancrr dans la plupart des états dans la région.

\section{Introduction}

Cancers, and specifically carcinomas, of the head and neck vary widely between populations and have been associated with various known predisposing/retiologic factors like tobacco use ${ }^{1}$; alcohol ingestion and smoked foods ${ }^{2}$; chinese-style salted foods ${ }^{3}$; very hol drinks ${ }^{4}$; viruses and industrial pollution ${ }^{5}$. The associatic $n$ of these predisposing factors with head and neck canc ers make these cancers preventable and controllable follo ving early diagnosis ${ }^{1}$.

Global epidemiology shows that head and neck cancers constitute between $5-50 \%$ of all cancers ${ }^{6}$. In Nigeria, there is no true incidence for head and neck ca ncers, but studies in Jos and Lagos have reported an incidence of about 38 cases yearly ${ }^{7.8}$. The Ahmadu Bello University Teaching Hospital in Zaria, up until 1986, was the sole referral center for histopathology and specialis। management of head and neck malignancies for the whole of Northern Nigeria, with a greater coverage of the N.rth West zone. The long distances patients have had to 1 ravel discouraged early reporting of lesions and a detaled study of the natural history of the conditions due o loss of patients to follow up. The establishment of the University of Maiduguri Teaching Hospital (UMTH), the ( nly referral center for histopathology in North Easterı Nigeria, has led to an increased reporting of cancer case, from the zone". This hospital receives biopsies from ge vernment specialist and general hospitals, mission and pr vate hospitals (all serving a population of about 11.9 milli $m$ people) in the states within the zone.

This study is aimed at documenting the epider iological pattern of head and neck cancers in North Eastern Nigeria. 


\section{Materials and Methods}

The North Eastern region is made up of six states namely Bomo, Adamawa. Yobe, Gombe, Bauchi and Taraba States. It is hot and dry for the greater part of the year, with temperatures reaching as high as 40 degrees centigrade and relative humidity as low as $18 \%$.

The ethical clearance required to access data for the study was obtained from the Chief Medical Director of the hospital. Socio-demographic information and history of cancer management after the pattern of the Minimum Cancer Dataset ${ }^{10}$ developed by the British Association of Head and Neck Oncologists (BAHNO), were retrieved from pathology and medical records of patients diagnosed of cancers of the head and neck at the hospital from the inception of histopathology services in 1987 till December 2002 .

For the purpose of this study, head and neck cancers would be defined as primary malignant neoplasms of epithelial, connective and neural tissue origin or any lesion of unspecified cellular origin but showing histological features of a malignancy involving sites in the head and neck, as classified by the $10^{\text {th }}$ Version of the International Classification of Diseases (ICD-10). This excludes secondaries/metastases, benign neoplasms and reportable benign lesions of the head and neck.

Patients of ages " 0 - 14 years" and " $15+$ years" were defined as "children" and "adults", respectively, to conform with the standards reported by the International Agency for Research on Cancer (IARC). The clinical staging of cancers used in the study is as developed by the American Joint Committee on Cancer (AJCC)/UICC and is based on the TNM System ".

The data was analysed statistically using the SPSS $8+$ and Epi Info Version 6.0. Relationships between nominal data were determined using the Yates Corrected and Fischer's Exact Chi-square tests while associations between habits and cancers were determined using the Kruskal-Wallis and Kolmogorov-Smirnov Tests. The student's t-test was used to compare the duration of symptoms for different neoplasms. A p-value of 0.05 or less was considered significant.

\section{Results}

A total of 317 primary cancers of head and neck were seen at the hospital between 1987 and 2002, which translates to a yearly incidence of about 20 cases. Two Hundred and Eighty Three $(89.3 \%)$ of these were recorded in adults while $34(10.7 \%)$ were recorded in children (Table

Table 1 Distribution of primary head and neck cancers by age group

\begin{tabular}{|c|c|c|c|}
\hline Type of malignancy & $\begin{array}{l}\text { Age groups } \\
0-14\end{array}$ & $\begin{array}{l}\text { (Years) } \\
15-75+\end{array}$ & Total \\
\hline Carcinoma & 4 & 213 & 217 \\
\hline Sarcoma & 8 & 19 & 27 \\
\hline Lymphoma & 9 & 47 & 56 \\
\hline Retinoblastoma & 11 & 0 & 11 \\
\hline Others & 2 & 4 & 6 \\
\hline Total (\%) & $34(10.7)$ & \multicolumn{2}{|c|}{$283(89.3) 317$} \\
\hline
\end{tabular}

Table 2 Gender distribution and histologic types of cancers

\begin{tabular}{|c|c|c|c|c|c|}
\hline $\begin{array}{l}\text { Children } \\
\text { Cancer types }\end{array}$ & Male & $\begin{array}{l}\text { Gender } \\
\text { Female }\end{array}$ & Unspecified & Total & M-F ratio \\
\hline Carcinoma & 2 & 2 & - & 4 & $1: 1$ \\
\hline Sarcomas & 5 & 3 & - & 8 & $5: 3$ \\
\hline Lymphomas & 8 & 1 & - & 9 & $8: 1$ \\
\hline Retinoblastomas & 8 & 2 & I & 11 & $4: 1$ \\
\hline Leukemia & 1 & 0 & - & 1 & $1: 0$ \\
\hline Unspecified lesions & 0 & 1 & - & 1 & $0: 1$ \\
\hline Total & 24 & 9 & 1 & 34 & $8: 3$ \\
\hline \multicolumn{6}{|l|}{ Adults } \\
\hline \multirow[t]{2}{*}{ Cancertypes } & \multicolumn{2}{|c|}{ Gender } & & Total & M-F ratio \\
\hline & Male & Female & Unspecified & & \\
\hline Carcinoma & 125 & 83 & 5 & 213 & $3: 2$ \\
\hline Sarcomas & 10 & 9 & 0 & 19 & $1.1: 1$ \\
\hline Lymphomas & 38 & 8 & 1 & 47 & $4.7: 1$ \\
\hline CNS Lesions & 1 & 1 & 0 & 2 & $1: 1$ \\
\hline Multiple Myeloma & 1 & 0 & 0 & 1 & $\mathrm{I}: 0$ \\
\hline Clear cell Tumour & 0 & 1 & 0 & 1 & $0: 1$ \\
\hline Total & 175 & 102 & 6 & 283 & $1.7: 1$ \\
\hline
\end{tabular}


Table 3 Primary head and neck cancers by age group and ICD Sites $(n=317)$

\begin{tabular}{|c|c|c|c|c|c|c|}
\hline Sites & ICD- $10 \mathrm{No}$ & $\begin{array}{l}\text { Age gro } \\
0-14\end{array}$ & $\begin{array}{l}\text { ups (Years) } \\
15-75+\end{array}$ & Unspecified & Total & $\begin{array}{l}\text { Percentage ol' } \\
\text { II\&N Cincers }\end{array}$ \\
\hline Oral Cavity & $\mathrm{CO0-06}$ & 0 & 48 & 0 & 48 & 15.1 \\
\hline Nasopharynx & $\mathrm{C} 11$ & 3 & 30 & 1 & 34 & 10.7 \\
\hline Hodgkin's Disease & $\mathrm{C} 81$ & 4 & 27 & 2 & 33 & 10.4 \\
\hline Eye \& Adnexa & $\mathrm{C} 69$ & 11 & 19 & 0 & 30 & 9.5 \\
\hline Max. Antrum & $\mathrm{C} 31$ & 0 & 22 & 0 & 22 & 6.9 \\
\hline (Jaw) Bones & $\mathrm{C} 41$ & 4 & 17 & 0 & 21 & 6.6 \\
\hline Non-Hodgkin's lymphomas & $\mathrm{C} 82, \mathrm{C} 83 \& \mathrm{C} 85$ & 5 & 15 & 1 & 21 & 6.6 \\
\hline Nasal Cavity & $\mathrm{C} 30$ & 0 & 18 & 0 & 18 & 5.7 \\
\hline Salivary Glands & $\mathrm{C} 07, \mathrm{CO} 8$ & 1 & 17 & 0 & 18 & 5.7 \\
\hline Scalp & $\mathrm{C} 44$ & 2 & 16 & 0 & 18 & 5.7 \\
\hline Thyroid & $\mathrm{C} 73$ & 0 & 17 & 0 & 17 & 5.4 \\
\hline Larynx \& Vocal Cord & $\mathrm{C} 32$ & 1 & 14 & 0 & 15 & 4.7 \\
\hline *Unknown Primaries & & 2 & 6 & 0 & 8 & 2.5 \\
\hline Oropharynx & $\mathrm{C} 10$ & 0 & 5 & 0 & 5 & \\
\hline Hypopharynx & $\mathrm{C} 13$ & 0 & 3 & 0 & 3 & 0.9 \\
\hline Other Lymphomas & $\mathrm{C} 84$ & 0 & 2 & 0 & 2 & $0 . t$ \\
\hline Leukaemia & $\mathrm{C} 95$ & 1 & 0 & 0 & 1 & 0.3 \\
\hline Tonsil & $\mathrm{CO9}$ & 0 & 1 & 0 & 1 & $0 . .^{2}$ \\
\hline Eyelid & & 1 & 0 & 0 & 1 & 0.2 \\
\hline Post-auricular Skin & $\mathrm{C} 44$ & 0 & 1 & 0 & 1 & 0.2 \\
\hline Total $(\%)$ & & $35(11.0)$ & $278(87.7)$ & $4(1.3)$ & $317(100)$ & \\
\hline
\end{tabular}

*These cancers ( 3 carcinomas and 5 sarromas) were reported in the lymph nodes

1). Carcinomas, lymphomas and Sarcomas were more common in adults $(98.1 \%, 83.9 \%, 70.4 \%$ respectively), while retinoblastomas were reported only in children (Table 2 ).

\section{Histological distribution}

In children, epithelial tissue malignar cies constituted $24(70.6 \%)$ of all head and neck cancers, , ff which are

Table 4 Histological types of primary head and neck cancer by site

\begin{tabular}{|c|c|c|c|c|c|}
\hline \multirow[t]{2}{*}{ Sites } & \multicolumn{4}{|c|}{ Histologic types of cancers } & \multirow[t]{2}{*}{ Tot: 1} \\
\hline & Carcinomas & Sarcomas & Lymphomas & Others & \\
\hline *Lymph Nodes & 3 & 5 & 43 & 1 & 52 \\
\hline Oral Cavity & 44 & 4 & 0 & 0 & 48 \\
\hline Nasopharynx & 35 & 0 & 2 & 0 & 37 \\
\hline Eye \& Adnexa & 19 & 0 & 2 & $11 \% *$ & 32 \\
\hline Max. Antrum & 21 & 1 & 1 & 0 & 23 \\
\hline (Jaw) Bones & 11 & 9 & 2 & 1 & 23 \\
\hline Scalp & 10 & 6 & 0 & 2 & 18 \\
\hline Nasal Cavity & 16 & 1 & 2 & 1 & 20 \\
\hline Salivary Glands & 17 & 0 & 1 & 1 & 19 \\
\hline Thyroid & 17 & 0 & 0 & 0 & 17 \\
\hline Larynx \& Vocal Cord & 15 & 0 & 0 & 0 & 15 \\
\hline Oropharynx & 5 & 0 & 2 & 0 & 7 \\
\hline Hypopharynx & 3 & 0 & 0 & 0 & 3 \\
\hline Tonsil & 1 & 0 & 0 & 0 & 1 \\
\hline Eyelid & 0 & 0 & I & 0 & 1 \\
\hline Post-auricular Skin & 0 & 1 & 0 & 0 & I \\
\hline Total & $217(68.4)$ & $27(8.5)$ & $56(17.7)$ & $17(5.4)$ & 317 \\
\hline \multicolumn{6}{|c|}{ * . C81-C85, C95 \& unknown primaries } \\
\hline
\end{tabular}


Retinoblastomas $11(32.3 \%)$, Lymphomas $9(26.5 \%)$ and Carcinomas 4(11.8\%) (Table 2). Hodgkin's disease and Burkitt's lymphoma were the most common lymphomas reported, 4(44.4\%) each. Childhood Burkitt"s lymphoma constituted $66.7 \%$ of the total reported.

Rhabdomyosarcoma $3(37.5 \%)$, Kaposi sarcoma and Ewing's sarcoma 2(25\%) each and Dermatofibrosarcoma $1(12.5 \%)$ were the sarcomas reported in this series among children.

Squamous cell carcinoma and unspecified carcinoma constituting $50 \%$ were the primary childhood carcinomas reported.

In adults, cancers of epithelial tissue constituted $91.3 \%$ of reported head and neck cancers. Carcinomas constituted $85.5 \%$ of the epithelial malignancies reported, with a male-female ratio of 3:2. Hodgkin's disease 29(63.9\%) is the most common lymphoma reported in adults in this series. Two cases of Burkitt's lymphoma were reported exclusively in males in their $2^{\text {nd }}$ decade of life, with a mean age of occurrence of 19.5 years.

Kaposi sarcoma was the prevalent sarcoma in the adult population $(36.8 \%)$ and was more common than in children $(7: 2)$. Kaposi sarcomas constituted $2.8 \%$ of all head and neck cancers.

\section{Site and age distribution}

The epidemiology of specific sites is as follows:

Oral cavity - The oral cavity, for the purpose of this study, includes the lip, tongue, gingival, floor of the mouth, buccal mucosa, alveolus of maxilla and mandible, unspecified "mouth"/"oral cavity" and the palate. Cancers of this site included carcinomas 44(91.7) and sarcomas 4(8.3\%). Kaposi sarcoma is the only reported sarcoma in this site. The cancers occurred mostly in the $6^{\text {th }}$ decade, with an overall mean age of occurrence of $29.1 \pm 15.96$ years (males $=29.5 \pm 14.3$ years; females $=28.8 \pm 16.5$ years) and a M-F ratio of 1:1.3 (Tables 3-5).

Nasopharynx - Cancers of this site included carcinomas $35(94.6 \%)$ and non-Hodgkin's lymphoma 2(5.4\%). They were reported mostly in the $6^{\text {th }}$ decade of life, with an overall mean age of occurrence of $29.8 \pm 18.8$ years (males $=30.1 \pm 18.2$ years; females $=28 \pm 16.5$ years) and a M-F ratio of 5:1 (Tables 3-5).

Maxillary antrum - Cancers in this site included carcinomas 21 (91.4), non-Hodgkin's lymphoma 1 (4.3\%) and spindle cell sarcoma $1(4.3 \%)$. There were no childhood cancers reported. The cancers occurred mostly in the $3^{\text {rd }}$ decade of life, with an overall mean age of occurrence of $43.8 \pm 16.8$ years $($ males $=50.1 \pm 17.8$ years; females $=33.9 \pm$ 9.3 years) and a M-F ratio of 1.6:1 (Tables 3-5).

Larynx \& Vocal cord - Cancers of this site were exclusively squamous cell carcinomas. The only childhood cancer reported case was in a 14-year old male. The cancers were reported mostly in the $4^{\text {th }}$ decade of life, with a M-F ratio of $14: 1$ and an overall mean age of occurrence of $49.4 \pm 15.8$ years (male $=26.5 \pm 15.3$ years). The only female was 70 years old (Tables $3-5$ ).

Eye \& Adenexa - Cancers in this site included carcinomas $19(59.4 \%)$, retinoblastomas $11(34.4 \%)$ and lymphomas $2(6.2 \%)$. They occurred mostly in the $1^{\text {st }}$ decade of life, with an overall mean age of occurrence of $31.4 \pm 25.2$ years (males $=31.1 \pm 26.3$ years; females $=32.4 \pm 23.1$ years $)$ and a $\mathrm{M}$-F ratio of 3.4:1 (Tables 3-5).

Nose/Nasal cavity - Cancers in this site included carcinomas $16(80 \%)$, lymphomas $2(10 \%)$. Kaposi sarcoma and malignant neurogenic tumour constituted $1(10 \%)$ each. The cancers were reported mostly in the $3^{\text {rd }}, 4^{\text {th }}$ and $6^{\text {th }}$ decades of life, with an overall mean age of occurrence of

Table 5 Age distribution of primary head and neck cancers for different sites

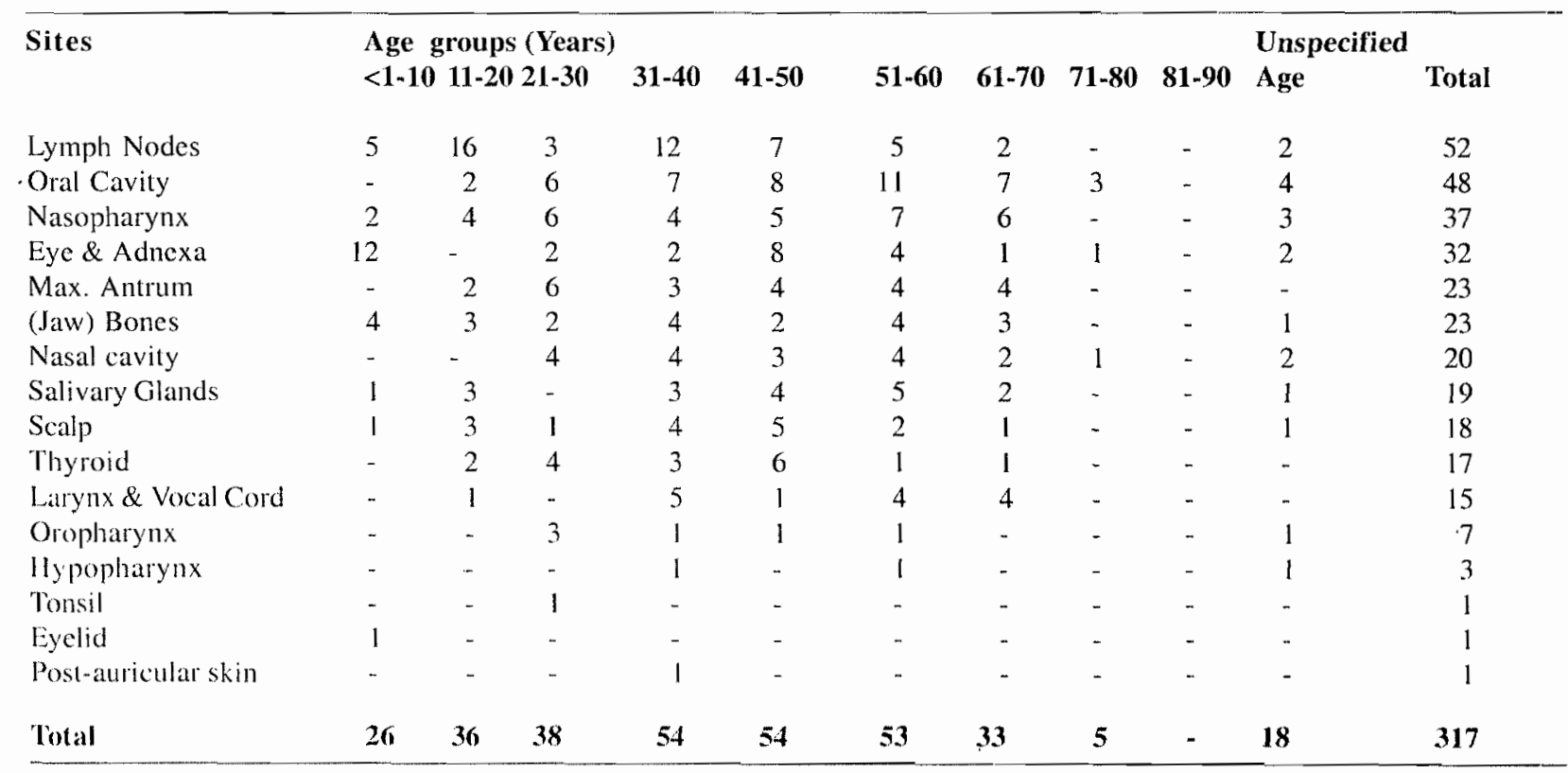


Table 6 Habits associated with head and neck Cancers (and Squamous Cell Ca.)

\begin{tabular}{llllll}
\hline & $\begin{array}{l}\text { Tobacco } \\
\text { Smoking }\end{array}$ & $\begin{array}{l}\text { Tobacco } \\
\text { chewing }\end{array}$ & $\begin{array}{l}\text { Itabits } \\
\text { Alcohol } \\
\text { use }\end{array}$ & $\begin{array}{l}\text { Kolanut } \\
\text { use }\end{array}$ & To ial \\
Carcinomas & 8 & 1 & 7 & 9 & 25 \\
Sarcomas & 1 & - & 2 & 2 & 5 \\
Lymphomas & 1 & - & 1 & 2 & 3 \\
Others & - & - & $\mathbf{1 0}$ & $\mathbf{1 3}$ & $\mathbf{3 4}$ \\
All Cancers & $\mathbf{1 0}$ & $\mathbf{1}$ & $\mathbf{4}$ & $\mathbf{6}$ & 15 \\
Sq. Cell Carcinoma & 4 & 1 & & & \\
\hline
\end{tabular}

$43.8 \pm 14.6$ years $($ males $=46.9 \pm 14.3$ years; females $=40 \pm$ 13.2 years) and a M-F ratio of 1.4:1 (Tables 3-5).

Thyroid gland - Cancers in this site were exclusively carcinomas and include follicular carcinoma $10(58.8 \%)$, medullary carcinoma $3(17.6 \%)$, anaplastic carcinoma $2(11.8 \%)$. Papillary carcinoma and squamous cell carcinoma constituted $1(5.9 \%)$ each of thyroid cancers. They were exclusively reported in adults in this series and occurred mostly in the $5^{\text {th }}$ decade, with an overall mean age of occurrence of $38.8 \pm 14.5$ years (males $=45:-4.1$ years; females $=36.8 \pm 16.1$ years) and a M-F ratio of 13.2 (Tables 3-5).

Major salivary glands - Cancers in these sites, were exclusively limited to the parotid gland (C07) a nd included carcinomas 17(89.4\%), Burkitt's lymphoma 1(5.3\%). A single case of an "unspecified malignant lesion" (5.3\%) was reported at this site in a child in this serics. The cancers were reported mostly in the $6^{\text {th }}$ decade of ife, with an

Table 7 Cancer journey by sites and cancer types

\begin{tabular}{|c|c|c|c|}
\hline Site(ICD-10) & $\begin{array}{l}\text { Interval } b / w \\
\text { symptoms \& } 1^{\text {st }} \\
\text { appointment (months) }\end{array}$ & $\begin{array}{l}\text { Interval b/w } \\
\text { referral \& 1st } \\
\text { appointment (days) }\end{array}$ & $\begin{array}{l}\text { Duration ir } \\
\text { admission (lays) }\end{array}$ \\
\hline Oral Cavity (C00-C06) & $17.0 \pm 19.6$ & $8.6 \pm 11.74$ & $21.5 \pm 27.0$ \\
\hline Nasopharynx (C11) & $8.4 \pm 9.23$ & $5.2 \pm 4.64$ & $13.2 \pm 13.9$ \\
\hline Max. Antrum (C31) & $18.5 \pm 29.66$ & $4.1 \pm 4.37$ & $9.4 \pm 8.35$ \\
\hline Larynx \& VC (C32) & $16.9 \pm 8.99$ & $11.6 \pm 8.08$ & $15.4 \pm 13.08$ \\
\hline Eye \& Adnexa (C69) & - & - & 15 \\
\hline Nose/Nasal Cavity (C30) & $32.1 \pm 33.97$ & $4.5 \pm 1.91$ & $16.4 \pm 21.1$ \\
\hline Thyroid Gland (C73) & $144.6 \pm 181.04$ & 25 & $14.1 \pm 14.5$ \\
\hline Salivary Glands (C07) & $72.4 \pm 95.9$ & - & $12.0 \pm 5.29$ \\
\hline Oropharynx (C10) & $12.0 \pm$ & -- & $9.0 \pm 0.00$ \\
\hline Hypopharynx (C13) & $2.0 \pm 0.00$ & - & $7.0 \pm 7.07$ \\
\hline Jaws (C41) & $17.7 \pm 21.17$ & $2.8 \pm 2.87$ & $10.8 \pm 7.19$ \\
\hline Scalp (C44) & $48.5 \pm 41.92$ & $3.0 \pm 1.73$ & $26.0 \pm 13.3$ \\
\hline Ear & 5.0 & - & 8.0 \\
\hline Face & 3.0 & - & - \\
\hline Eyelids & $24.00 \pm 0.00$ & - & 9.0 \\
\hline Mastoid & $34.2 \pm 22.54$ & - & 13.0 \\
\hline Lymph Nodes & $15.7 \pm 19.48$ & $26 \pm 21.38$ & $14.5 \pm 10.32$ \\
\hline Cancer type & $\begin{array}{l}\text { Interval b/w } \\
\text { symptoms \& } \\
\text { sst appointment (months) }\end{array}$ & $\begin{array}{l}\text { Interval b/w referral \& } \\
\text { tw appointment } \\
\text { (days) }\end{array}$ & $\begin{array}{l}\text { Duration i/l } \\
\text { admission(lays) }\end{array}$ \\
\hline Carcinoma & $31.2 \pm 66.7$ & $7.4 \pm 8.6$ & $14.9 \pm 16.4$ \\
\hline Sarcomas & $28.4 \pm 39.3$ & $8.8 \pm 16.9$ & $11.1 \pm 6.1$ \\
\hline Lymphomas & $9.6 \pm 8.3$ & $* 2.0$ & $13.1 \pm 9.0$ \\
\hline Others & $4.5 \pm 2.1$ & $* 5.0$ & $13.7 \pm 1.1$ \\
\hline
\end{tabular}

Information from one patient only" 
Table 8 Frequency distribution of stages at presentation by cancer types

\section{Cancer types}

TNM Stage ${ }^{10}$

Total (\%)

\begin{tabular}{lllcrr} 
& I & II & III & IV & \\
Carcinomas & 0 & 2 & 10 & 49 & 51 \\
Sarcomas & 0 & 0 & 1 & 1 & 6 \\
Others & 0 & 0 & 0 & $\mathbf{5 5 ( 8 0 . 9 )}$ & $\mathbf{6 8}$ \\
All Cancers $(\%)$ & $\mathbf{0 ( 0 )}$ & $\mathbf{2 ( 2 . 9 )}$ & $\mathbf{1 1 ( 1 6 . 2 )}$ & & \\
\hline
\end{tabular}

overall mean age of occurrence of $43.9 \pm 18.4$ years (males $=43.5 \pm 21.2$ years; females $=45.2 \pm 8.9$ years) and a M-F ratio of 2.6:I (Tables 3-5).

Oropharynx - Cancers in this site included carcinomas $5(71.4 \%)$ and non-Hodgkin's lymphoma 2(28.6\%). They occurred mostly in males (M-F ratio $=6: 1$ ) in the $3^{\text {rd }}$ decade of life, with an overall mean age of occurrence of $36.5 \pm$ 10.8 years (males $=32.8 \pm 6.5$ years). The only female was 55 years old (Tables $3-5$ ).

Hypopharynx - The only malignancy reported in this site is the squamous cell carcinoma, which was reported mostly in females $(M-F$ ratio $=1: 2$ ), in the $40-55$ years age range, with a mean age of occurrence of $47.5 \pm 10.6$ years (Tables 3-5).

Jaws - Cancers reported in this site were carcinomas $11(47.8 \%)$, sarcomas $9(39.1 \%)$, (Burkitt's) 1ymphoma $2(8.7 \%)$ and multiple myeloma $1(4.3 \%)$. They occurred mostly in the $1^{\text {st }}, 4^{\text {th }}$ and $6^{\text {th }}$ decades of life, with an overall mean age of occurrence of $37.1 \pm 22.1$ years (males $=35.5 \pm$ 25.0 years; females $=39.1 \pm 19.1$ years) and $M-F$ ratio of 1.1:1 (Tables 3-5).

Scalp - Cancers of this site included carcinoma 10(55.6\%), sarcomas $6(33.3 \%)$, clear cell tumour $1(5.5 \%)$ and malignant meningioma $1(5.5 \%)$. They were reported mostly in the $5^{\text {th }}$ decade of life, with an overall mean age of occurrence of $39.3 \pm 16.9$ years (males $=37.8 \pm 16.95$ years; females $=41 \pm 17.9$ years) and a M-F ratio of 1.1:1 (Tables 3$5)$.

Lymph Nodes - Cancers in this site were exclusively lymphomas $43(82.7 \%)$, cancers of unknown primary site $8(15.4 \%)$ and leukemia $1(1.9 \%)$. The affected sites are cervical nodes $36(69.2 \%)$, supraclavicular nodes $3(5.8 \%)$ and unspecified nodes $13(25 \%)$. The cancers presented mostly in the $2^{\text {itd }}$ decade with an overall mean age of occurrence of $30.9 \pm 17.5$ years (male $=31.7 \pm 17.0$ years: females $=28.8$ \pm 19.3 years) and a M-F ratio of 2.9: I (Tables 3-5).

\section{Risk factor assessment among cancer patients}

A total of 143 patients were questioned about habits, of which 34 patients gave histories of tobacco smoking, tobacco chewing, alcohol use and the chewing of kola nuts. No patient reported using nasal snuff. There were no enquiries into the use of oral snuff and fuel sucking. The common practices associated with head and neck cancers were kola nut use $13(38.2 \%, \mathrm{p}<0.05)$, tobacco use $11(32.3 \%)$ and alcohol use $10(29.4 \%)$. Kola nut chewing was commonly associated $(\mathrm{p}<0.05)$ with carcinomas and squamous cell carcinomas $(36 \%, 40 \%)$.

\section{Interval between symptoms and presentation (duration} of symptoms of cancers)

A total of 143 files of patients treated for head and neck malignancies at the hospital had information on the history of the condition. Of these, the mean interval between onset of symptoms and $1^{\text {st }}$ appointment at the hospital was $32.4 \pm 77.2$ months. Patients with carcinomas manifested symptoms for a longer duration than those with sarcomas $(p>0.05)$ and lymphomas $(p=0.05)$.

\section{Stage at presentation of cancers}

A total of 68 cases had the TNM staging recorded. The earliest presenting cancers were stage II $\left(\mathrm{T}_{2} \mathrm{~N}_{0} \mathrm{M}_{0}\right)$ carcinomas $(2.9 \%)$. All the other cancer cases were diagnosed at the stage III $\left(\mathrm{T}_{3} \mathrm{~N}_{0} \mathrm{M}_{0}\right.$ and any $\left.\mathrm{T}, \mathrm{N}_{1} \mathrm{M}_{0}\right)$ and stage IV (any $\mathrm{T}, \mathrm{N}_{2} \mathrm{M}_{0}$; and any $\mathrm{T}$ or $\mathrm{N}, \mathrm{M}_{1}$ ) of head and neck cancers.

\section{Cancers and associated occupation}

Carcinoma, sarcoma and lymphomas were commonly reported among farmers. $81 \%$ and $83.3 \%$ of farmers and house-wives (who double as farmers) were diagnosed for carcinoma $(n=47 \& 30)$, respectively.

\section{HIV status and head and neck cancers}

Investigations into the HIV status were carried out in 12 patients of the 143 whose files were retrieved at the hospital. Of these, 3 patients ( $25 \%$ ) were HIV positive, $6(50 \%)$ 
Table 9 Frequency of treatment modalities by cancer types

\begin{tabular}{|c|c|c|c|c|c|}
\hline \multirow[t]{2}{*}{ Cancer types } & \multicolumn{4}{|c|}{ Treatment modalities } & \multirow[b]{2}{*}{ Total } \\
\hline & Surgery & Chemotherapy & Radiotherapy & $\begin{array}{l}\text { Combination } \\
\text { therapies }\end{array}$ & \\
\hline Carcinomas & 32 & 3 & 38 & 7 & 80 \\
\hline Sarcomas & 4 & 1 & 1 & 2 & 8 \\
\hline Lymphomas & 1 & 3 & 1 & 2 & 7 \\
\hline Others & 1 & 0 & 0 & 0 & 1 \\
\hline What $(\%)$ & $32(39.6)$ & $7(7.3 \%)$ & $46(4.47)$ & $11(1.5)$ & 96 \\
\hline
\end{tabular}

Frequency of condonation therapies by cancer lypes

Cancer types

Treament modalities

$\begin{array}{cl}\text { Surgery of } & \text { Surgery }+ \\ \text { Chemolnerapy } & \text { Lhadiotherapy }\end{array}$

Chenotherapy+ Surgery +

Radiotherapy Chemotherapy th Wotal

Radiotherapy

\begin{tabular}{|c|c|c|c|c|c|}
\hline Carcinomas & 0 & 5 & 1 & 1 & 7 \\
\hline Sarcomas & 1 & 0 & 0 & 1 & 2 \\
\hline Lymphomas & 1 & 1 & 0 & 0 & 2 \\
\hline "Totall & 2 & 6 & 1 & 2 & Ir \\
\hline
\end{tabular}

Table 10 Comparison of the prevalence of cancers of the nasopharynx, oro-pharynx, hypopharynx ar d larynx in under- 40 year olds in different studies

\begin{tabular}{|c|c|c|c|c|}
\hline Study Locations & $<40$ yr olds & Other ages & $X^{2}$ & p-value \\
\hline Maiduguri (This study) & 27 & 32 & 2.48 & 0.11 \\
\hline Lagos ${ }^{8}$ & 41 & 85 & & \\
\hline Study Locations & $<40 \mathrm{yr}$ olds & Other ages & $\mathbf{X}^{2}$ & p-value \\
\hline Maiduguri (This study) & 27 & 32 & 491.0 & 0.0000 \\
\hline Mass. USA ${ }^{12}$ & 36 & 2664 & & \\
\hline Study Locations & $<40 \mathrm{yr}$ olds & Other ages & $\mathrm{X}^{2}$ & p-value \\
\hline $\operatorname{Lagos}^{8}$ & 41 & 85 & 430.6 & 0.0000 \\
\hline Mass. USA '? & 36 & 2664 & & \\
\hline
\end{tabular}

were negative and 3 others were tested but unconfirmed cases whose results were not available as at the time of the study. HIV screening tests were not conducted for the majority of the cases. Kaposi sarcoma $2(66.7 \%)$ was the malignancy commonly associated with HIV sero-posi- tivity, with the oral cavity (gingiva and buce I mucosa) and nose being the affected sites. The male-fomale ratio of those with positive HIV test is 2 : I with an or erall mean age of $35 \pm 7.5$ years (male $=39 \pm 4.2$ years; emale $=27$ years). 


\section{Treatment modalities of cancers}

Information about treatment modalities was retrieved in $96(30.3 \%)$ cases. The treatments prescribed for head and neck cancers were radiotherapy $(41.7 \%)$, surgery $(39.6 \%)$, combination therapies $(11.4 \%)$ and chemotherapy (7.3\%). Radiotherapy, surgery and chemotherapy were the most common treatments for carcinomas, sarcomas and lymphomas respectively.

\section{Discussion}

Previous studies on head and neck cancers showed variations in the "inclusion criteria" for neoplasms and sites. While some focused solely on malignant neoplasms, other studies included reportable benign neoplasms of sites like the salivary glands, jaws and thyroid glands. This, expectedly, would give varying figures for the proportion of cancers of specific sites, in relation to the total head and neck cancers. Similarly, the ICD-10 has broadened the scope of sites involved in the oral cavity to more than the lip, tongue and palate reported in the study by Nwawolo and others ${ }^{8}$. There is a need for uniformity for appropriate comparison of results of studies, which would be limited to those studies with identical criteria.

The yearly hospital incidence of 20 cases of head and neck cancers reported in this study is less than the 38 and 24 reported for Lagos and Jos respectively ${ }^{7,8}$. The prevalence of cancers in the oral cavity relative to other head and neck sites in this study, contrasts with the findings of Nwawolo and others who reported the prevalence in the nasopharynx ${ }^{8}$. Bhatia reported a prevalence of head and neck cancers in the neck with no specific site in the neck noted ${ }^{7}$. This study also reported a significantly higher occurrence of cancers in the oral cavity than reported by Nwawolo and others for Lagos $(p=0.029)^{8}$. Cancers of the maxillary antrum were reported more commonly in Lagos than in this study $(\mathrm{p}<0.05)^{12}$; while there was no significant difference between the proportions of nasopharyngeal cancers reported in Lagos and in this study $(\mathrm{p}=0.07)^{8}$.

These variations in the primary sites and ages of occurrence between the North East, South West and North Central regions of Nigeria could also be attributed to the variations in the aetiological factors for cancers in the areas served by the different centers where the studies were conducted. There is therefore the need for further studies in the other geo-political zones in the country. A comparison of the prevalence of nasopharyngeal, oropharyngeal, hypopharyngeal and laryngeal cancers in under 40 year olds in this study with studies in Lagos and the USA showed that there is a higher occurrence of cancers in this age group in Maiduguri than in Lagos $\left(x^{2}=2.48\right.$, $p=0.11)$ and the USA $\left(x^{2}=491.0, p=0.000\right)^{s .13}$. This is a reflection of the increasing exposure of people in the age group to the carcinogenic agents in the environment, the late reporting of cancers to hospitals and inadequate (and where available, the uneven spread of) diagnostic facilities in the region and in Nigeria.
The gender distribution of cancers of the nasopharynx and maxillary antrum agrees with previously reported findings in Lagos ${ }^{8,12}$, but the prevalence of oral cancer in females in this study differs significantly ( $p=0.008$ ) from that reported in Lagos ${ }^{8}$. This difference could be attributed to the increasing exposure of females to carcinogenic agents like tobacco and ultra violet radiation.

The duration of symptoms for this study is longer than reported in previous Nigerian studies ${ }^{7,12}$. This could be attributed to cancer characteristics (low invasiveness and propensity to metastasize); cancer site, the nature of adjoining tissues (in this study, patients with cancers of sites that are important in speech, hearing, mastication and facial aesthetics reported earlier than patients with cancers in areas that are visible but without aesthetic, masticatory or phonetic importance) and the absence of painful symptoms. The initial recourse to traditional medicine, poor socio-economic status of the patients and the non-availability of a referral hospital with adequate histopathology facilities and appropriate manpower for the management of head and neck cancers in the states (except Borno) could also have influenced the late reporting to the hospital ${ }^{14.15}$.

The prevalence of cancers, especially carcinomas among farmers could be related to the long exposure to the sun and the composition of some of the chemical fertilizers used by the farmers, which may contain substances with carcinogenic risks ${ }^{15}$

Kolanut chewing and tobacco use have been associated with these cancers especially oral cancers. Kola nut (Cola acuminata and Cola nitida rubra) has been reported to promote the keratinization of palatal mucosa of cigarrete smokers ${ }^{17}$. Its co-carcinogenic potential may be related to its composition of caffeine $1-2 \%$, tannoids (especially condensed tannin) 5-10\%, traces of theobromine ${ }^{18}$. Tannins have been listed among compounds with known and suspected carcinogenic activity 19,20 .

The association of Kaposi sarcoma with HIV-positive patients agrees with reported findings from previously reported studies ${ }^{21,22}$. Patton and others ${ }^{23}$ showed the prevalence among homosexual males, but the information on the sexual practices of affected patients were not available in this study. There is a need for a detailed study on the cancer types associated with confirmed HIV patients and patients with clinical manifestations of the Acquired Immune Deficiency Syndrome (AIDS).

The observation of the non-entry of information on the modalities of treatment in $221(69.7 \%)$ of the 317 cases of primary head and neck cancers is significantly higher than expected $(p<0.05)$. This informs the need for a more detailed clerking and the orderly entry of information in the patient case notes and an update of the existing cancer registry in the hospital.

The treatment modalities for head and neck cancers were found to vary with the histological type and the stage at presentation of the malignancy. The prevalence of radiotherapy in the treatment of cancers agrees with the findings in the management of malignant tumours of 
the maxillary antrum in Ibadan ${ }^{24}$. This is as a result of the late presentation and previous manipulations of the cancers prior to reporting for treatment at the hospital ${ }^{1.5}$.

\section{Conclusion}

Intra-oral carcinomas are the most common histological types of cancers in the head and neck. The delay before, and the cancer stage at presentation, may be due to the lack of cancer management facilities and manpower in most of the hospitals in the region.

\section{Acknowledgement}

The fund for this research was provided by a grant from the Regional Centre for Oral Health Research and Training Initiatives (RCORTI) for Africa, Jos, Nigeria.

Our sincere appreciation goes to the Management, the Heads of the Histopathology and Medical Records Departments and the Cancer Registry Manager of the University of Maiduguri Teaching Hospital for their approval and kind contributions in the retrieval of the required data.

\section{References}

1. Johnson NW. Orofacial neoplasms: global epidemiology, risk factors and recommendations for research. Int Dent J 1991; 41: 365-375.

2. Sisson GA, Toriumi DM, Atiyah RA. Paranasal sinus malignancy - A comprchensive update. Laryngoscope $1989 ; 143-152$.

3. Yu MC. Nasopharyngeal carcinoma: epidemiology and dietary factors. In: Relevance to human cancer of $\mathrm{N}$ nitroso compounds, tobacco smoke and mycotoxins. O'Neill IK, Chen J, Bartsch H (eds).IARC Sci Publ, No. 105. 1991; p.39-47.

4. Key TJ, Allen NE, Spencer EA, Travis RC. The effect of diet on risk of cancer. Lancet 2002; 360: 861-68.

5. Evaluation of Carcinogenic Risks to Humans. IARC Monogr Carcinog Risks Hum, Internal Report 1998; No. 98/004, Vol.77.

6. Garfinkel L. Perspective on cancer prevention. Cancer J Clin. 1995; 45:5-9.

7. Bhatia PL. Head and neck cancer in Plateau State of Nigeria. WAJM 1990; 9: 304-310.

8. Nwawolo CC, Ajekigbe AT, Oyeneyin JO, Nwankwo $\mathrm{KC}$, Okeowo PA. Pattern of head and neck cancers among Nigerians in Lagos. WAJM 2001; 20: 111-116.

9. Adekeye EO, Robertson JM. Salivary gland tumours in Northern Nigeria. Tropical Doctor 1979; October: 168174.
10. Wight R. BAHNO National Minimum an 1 Advisory Head and Neck Data Sets. Version I.0. Lon Jon. 1999.

11. Carew JF, Singh B, Shah JP. Workup and : itaging. In: Oral Cancers. London: Shah JP, Johnson N'N, Batsakis JG (eds). Martin Dunitz: 2003. p.201-207.

12. Arotiba GT. Malignant ncoplasms of the maxillary antrum in Nigerians. WAJM 1998; 17: 173 178.

13. Camiol PJ. Head and ncck carcinoma in patients under 40 years of age. Ann Otol $1982 ; 91: 152-1 \leq 5$.

14. Oji C. Late presentation of orofacial rumours. J Craniomaxillofac Surg 1999; 27:1-6.

15. Solanke TF. Cancer in the Nigerian setting. Archives of lbadan Medicine 2000; 1: 3-5.

16. Evaluation of Carcinogenic Risks to Hur ans. IARC Monogr Carcinog Risks Hum, 1992 Vol.54 p. 41.

17. Odukoya O, Roberts T, Arole G. A cytolog ic study of the effects of kola nuts on the keratinisation o the palatal mucosa of Nigcrian smokers. African Der tal Journal $1990 ; 4: 1-5$.

18. Trease GE, Evans WC. Pharmacognosy. London. Bailliere Tindall. $13^{\text {th }}$ Edition. 1989 pp.629.

19. Selkirk JK. Chemical carcinogens: A brief c verview of the mechanisms of action of polycyclic hyc rocarbons, aromatic amines, nitrosamines and aflitoxin. In: Carcinogenesis Vol.5: modifiers of chemical carcinogens. Slaga TJ (ed). New York. Raven ?ress.1980; pp.24-25.

20. Evaluation of Carcinogenic Risks to Humans. IARC Monogr Carcinog Risks Hum, 1991 Vol.51. p.291.

21. Greenspan JS, Greenspan D. The epidemic logy of the oral lesions of HIV infection in the develcped world. Oral Diseases 2002; 8 (suppl.2): 34-39.

22. Holmes HK, Stephen LXG. Oral lesio is of HIV infection in developing countries. Oral Discases 2002; 8(suppl. 2): 40-43.

23. Patton LL, Phelon IA, Ramos-Gomez FJ, Nittayananta W, Shiboski $\mathrm{CH}$, Mbuguye TL. Prevalence and classification of HIV-related oral lesions. Oral Diseases 2002; 8(suppl.2): 98-109.

Campbell OB, Adeosun AB, Arotiba JT, A sinlade BI, Obed RI. Management of malignant tum surs of the maxillary antrum in lbadan, Nigeria,- 1 Re-visit. Nigerian Joumal of Clinical Practice $2000 ;: 1$ : -4 . 